Situs Jurnal : $\underline{\text { http://ejournal.stiepancasetia.ac.id/index.php/jieb }}$

Jilid 5 Nomor 2 Juli 2019

Hal 164 - 176

\title{
PENGARUH KINERJA KEUANGAN TERHADAP HARGA SAHAM PERUSAHAAN PERBANKAN BUMN DI BURSA EFEK INDONESIA PERIODE TAHUN 2010-2017
}

\author{
Defry Wijaya Rimba \& Muthia Harnida*
}

Abstract: The aim of this research is to examine the effect of financial performance on the stock prices of state-owned (BUMN) banking companies in the Indonesian Stock Exchange for the period 2010-2017.The financialperformance consists of Non Performing Loans, Return on Assets, Capital Adequacy Ratio, Price Earning Ratio, and Net Profit Margin. The analysis in this study used the multiple linier regression with 32 observations. Simultaneously all variables affect the stock price of Banking Companies of BUMN that listed on the Indonesian Stock Exchange for the period of 2010-2017. But partially, the variables which affect the stock price are only Return On Assets, Capital Adequacy Ratio, and Net Profit Margin. Whereas the variable of Non Performing Loans and Price Earning Ratio do not affect the stock price of Banking Companies of BUMN in the Indonesian Stock Exchange for the period of 2010 until 2017

Keywords: Performance, Non Performing Loans, Return On Assets, Capital Adequacy Ratio, Price Earning Ratio, Net Profit Margin, Stock Price

Abstrak: Tujuan penelitian ini adalah untuk menguji pengaruh kinerja keuangan terhadap harga saham pada perusahaan perbankan BUMN yang terdaftar di Bursa Efek Indonesia untuk periode 2010-2017. Kinerja keuangan yang diuji meliputi Non performace Loans (NPL), Return on assets (ROA), CapitalAdequacy Ratio (CAR), Price Earnings Ratio(PER),dan Net Profit Margin (NPM). Hasil penelitian dengan menggunakan analisis regresi linier berganda,dengan sampel sebanyak 32 observasi menunjukkkan hasil bahwa secara simultan semua variabel yang terdiri dari Non performace Loans (NPL), Return on assets (ROA), CapitalAdequacy Ratio (CAR), Price Earnings Ratio(PER),dan Net Profit Margin (NPM) berpengaruh terhadap harga saham . Sedangkan secara parsial variabel yang berpengaruh terhadap harga saham adalah return on assets (ROA), CapitalAdequacy Ratio (CAR), dan Net Profit Margin (NPM), sementara Non Performing Loans (NPL) dan Price Earnings Ratio (PER) secara statistik tidak berpengaruh terhadap harga saham perusahan perbankan BUMN yang terdaftar di Bursa Efek Indonesia untuk periode pengamatan 2010-2017

Kata kunci : Kinerja, Non Performing Loans, Return On Assets, Capital Adequacy Ratio, Price Earning Ratio, Net Profit Margin, harga saham

\section{Latar Belakang}

Investasi saham sedang sangat digalakkan oleh pemerintah Indonesia. Ada lebih dari 400 emiten saham yang sahamnya diperjualbelikan di Bursa Efek Indonesia dan transaksinya diawasi oleh Otoritas Jasa Keuangan. Diantara investasi yang disebutkan di atas, saham adalah investasi dengan risiko paling tinggi namun juga tidak dipungkiri bahwa saham dapat memberikan keuntungan yang juga paling tinggi jika kita dapat menganalisis informasiinformasi yang dapat memengaruhi perubahan harga saham. 
Laporan keuangan yang merupakan pertanggungjawaban perusahaan memiliki banyak unsur yang menjadi perhatian baik bagi calon investor maupun investor lama. Contohnya perusahaan perbankan yang usahanya menyalurkan dana dari orang yang berkelebihan dana ke orang yang memerlukan dana dalam bentuk pinjaman/kredit. Menurut Peraturan BI no. 13 tahun 2011 perusahaan ini memiliki beberapa aspek yang perlu diperhatikan seperti risiko kredit, pendapatan, dan likuiditas dimana aspek tersebut merupakan unsur perusahaan secara fundamental dan tentunya bagi investor laba juga termasuk informasi yang sangat penting dalam hal ini laba yang dimaksud adalah Capital Gain dan Dividen.

Untuk mengukur risiko kredit terdapat dua rasio yaitu Non Performing Loan (NPL) atau Loan to Deposit Ratio (LDR). Dalam penelitian ini rasio yang digunakan adalah Non Performing Loan. Rasio ini dipilih sebab memberikan gambaran risiko yang lebih spesifik yaitu risiko kredit. Rasio ini membandingkan total kredit macet terhadap total kredit. Semakin kecil hasil dari rasio ini berarti kinerja perkreditan bank semakin baik dan pada akhirnya akan meningkatkan perolehan laba. Menurut Peraturan Bank Indonesia bank yang sehat memiliki rasio NPL $<8 \%$.

Untuk mengukur pendapatan dapat menggunakan rasio Return On Asset (ROA). Rasio ini dihitung dengan membandingkan laba sebelum pajak dengan total aset. Dengan rasio ini kita dapat melihat kemampuan aset yang dimiliki dalam menghasilkan laba. Semakin tinggi nilai rasio berarti kinerja perusahaan juga semakin baik. Menurut Peraturan Bank Indonesia bank yang sehat memiliki rasio $\mathrm{ROA}<0,5 \%$.

Untuk mengukur likuiditas dapat menggunakan rasio Capital Adequacy Ratio (CAR). Semakin tinggi CAR bank menunjukkan kemampuan bank untuk menanggulangi risiko semakin baik dan semakin besar peluang bank untuk menyalurkan kredit, sehingga lebih memberikan keyakinan kepada pemegang saham atau investor akan kelangsungan operasional bank. Tinggi rendahnya Kewajiban Penyediaan Modal Minimum atau CAR suatu bank akan dipengaruhi oleh 2 faktor utama yaitu besarnya modal yang dimiliki bank dan jumlah Aktiva Tertimbang Menurut Risiko (ATMR) yang dikelola oleh bank tersebut. Ketentuan Bank Indonesia menyatakan bahwa suatu bank dikatakan sehat apabila Bank memiliki rasio CAR sebesar minimal $8 \%$.

Laba per saham menggambarkan bagaimana keuntungan perusahaan atau emiten saham terhadap harga sahamnya. Selain itu dengan laba per saham ini investor juga dapat mengetahui berapa lama waktu yang diperlukan untuk memperoleh modalnya kembali. Rasio yang digunakan adalah Price Earning Ratio (PER). PER adalah suatu teknik analisis teknikal untuk menggambarkan kesempatan dalam memperoleh capital gain yang sering digunakan oleh investor yaitu hanya dengan membandingkan harga saham dengan laba per sahamnya karena informasi akun tersebut sangat mudah diperoleh oleh para investor.

Ratri (2015) meneliti tentang "Pengaruh Kinerja Keuangan Terhadap Harga Saham Perusahaan Tekstil dan Produk Tekstil (TPT) yang Terdaftar di Bursa Efek Indonesia Tahun 2009-2014" Hasil penelitiannya menunjukkan bahwa Dept to Equity Ratio (DER), Return On Equity (ROE), Inventory Turnover Ratio (ITO) berpengaruh signifikan terhadap harga saham sedangkan Cash Ratio (CR) dan Price Earning Ratio (PER) tidak berpengaruh secara signifikan terhadap harga saham.

Penelitian Apriliyanti (2015), menunjukkan bahwa faktor-faktor yang berpengaruh terhadap harga saham adalah Price Earning Ratio (PER),current ratio, dan return on equity, , sedangkan turn over inventory dan turn over receicable dan Capital Adequacy Ratio (CAR) tidak berpengaruh secara signifikan terhadap harga saham.

Penelitian Wardani (2018) juga mendukung penelitian Aprilianti (2015), dimana return on equity (ROE) juga berpengaruh terhadap harga saham, sementara price earnings ratio tidak 
berpengaruh terhadap harga saham. Menurut penelitian Halim,(2018) yang juga meneliti tentang "Faktor-Faktor yang Memengaruhi Harga Saham Pada Perusahaan Property dan Real Estate yang Terdaftar di Bursa Efek Indonesia"Hasil penelitiannya menyatakan bahwa Price Earning Ratio (PER) dan Earning Per Share (EPS) berpengaruh signifikan terhadap harga saham sedangkan Return on Equity (ROE), Debt to Equity Ratio (DER), dan Total Asset Turnover (TATO) tidak berpengaruh secara signifikan terhadap harga saham.

Ketidakkonsistenan hasil-hasil penelitian tersebut mendorong penulis untuk menguji kembali pengaruh kinerja keuangan yakni variabel-variabel yang terdiri dari Non Performing Loan (NPL), Return on asserts (ROA), Capital Adequacy Ratio (CAR), price earnings ratio (PER), dan net profit margin (NPM) terhadap harga saham, pada perusahaan perbankan BUMN yang terdaftar di Bursa Efek Indonesia periode 2010-2017.

\section{Kajian Literatur}

Beberapa kajian teori yang mendasari penelitian dan menjadi bahan untuk merancang hipotesis pada penelitian ini dapat disajikan sebagai berikut:

1. Hubungan Antara Non Performing Loan (NPL) Terhadap Harga Saham

Indikator yang dipergunakan untuk mengukur kualitas kredit adalah Non Performing Loan (NPL). Hasil penelitian (Marwansyah, 2016) menyatakan Non Performing Loan (NPL) berpengaruh signifikan terhadap harga saham. Non Performing Loan (NPL) menunjukkan besarnya kredit macet yang dimiliki suatu bank maka semakin besar nilai rasionya berarti semakin besar juga kredit macetnya dan semakin banyak kredit macet yang dimiliki berarti semakin banyak kredit mengurangi pendapatan perusahaan yang mana turunnya pendapatan mengakibatkan turunnya harga saham. Oleh karena itu ditarik hipotesis sebagai berikut.

H1: Non Performing Loan (NPL) berpengaruh negatif terhadap harga saham.

2. Hubungan Antara Return On Asset (ROA) Terhadap Harga Saham

Pengertian laba yang dianut oleh stuktur akuntansi didefinisikan sebagai selisih antara pengukuran pendapatan yang direalisasi dan transaksi yang terjadi dalam satu periode dengan biaya yang berkaitan dengan pendapatan tersebut (Cahriri \& Ghozali, 2007). Indikator yang dipergunakan untuk mengukur laba (rentabilitas) adalah Return Of Asset (ROA). Hasil penelitian (Marwansyah, 2016) menyatakan Return On Asset (ROA) berpengaruh signifikan terhadap harga saham. Return On Asset (ROA) menunjukkan besarnya perputaran aset suatu perusahaan semakin besar rasionya berarti semakin besar pendapatan yang diperoleh dari asetnya. Semakin besar pendapatan berarti memberikan peningkatan terhadap harga saham. Oleh karena itu ditarik hipotesis sebagai berikut.

H2: Return On Asset (ROA) berpengaruh positif terhadap harga saham.

3. Hubungan Antara Capital Adequacy Ratio (CAR) Terhadap Harga Saham

Modal adalah dana yang ditempatkan pihak pemegang saham yaitu pihak pertama pada bank yang memiliki peranan sangat penting sebagai penyerap jika timbul kerugian (risk loss). Aspek permodalan dinilai berdasarkan pada Kewajiban Kecukupan Penyediaan Modal Minimum (KPMM) yang diukur dengan Capital Adequacy Ratio (CAR). Hasil penelitian (Marwansyah, 2016) menyatakan Capital Adequacy Ratio (CAR) tidak berpengaruh signifikan terhadap harga saham. Capital Adequacy Ratio (CAR) menunjukan besarnya penggunaan modal untuk memenuhi kredit menurut resiko, semakin besar rasionya berarti semakin besar modal sendiri yang digunakan. Semakin besar modal memberikan 
kesempatan untuk memperoleh laba lebih banyak. Oleh karena itu hipotesis yang dikembangkan sebagai berikut.

H3: Capital Adequacy Ratio (CAR) berpengaruh positif terhadap harga saham.

4. Hubungan Antara Price Earning Ratio (PER) Terhadap Harga Saham

Pendapatan dari kepemilikan saham pada suatu perusahaan dapat berupa dividen maupun capital gain. Dividen sendiri adalah pembagian dari sebagian laba per saham dimana dengan melihat rasionya kita dapat mengetahui berapa lama waktu yang diperlukan untuk mendapatkan modal kita kembali. Rasio valuasi investasi dapat diukur dengan Price Earning Ratio (PER), rasio ini menunjukkan perbandingan antara harga saham dipasar yang ditawarkan dibandingkan dengan pendapatan yang diterima. Hasil penelitian (Halim, 2018) menyatakan Price Earning Ratio (PER) berpengaruh signifikan terhadap harga saham. Price Earning Ratio (PER) menunjukan lamanya waktu pengembalian modal perolehan saham perusahaan semakin besar rasionya berarti semakin cepat cepat perputaran sahamnya. Yang bisa berarti juga dikarenakan rendahnya harga saham. Oleh karena itu ditarik hipotesis sebagai berikut.

H4: Price Earning Ratio (PER) berpengaruh negatif terhadap harga saham.

5. Hubungan Antara Net Profit Margin (NPM) Terhadap Harga Saham

Laba yang tinggi menandakan manajemen berhasil mengelola perusahaannya dengan efisien. Laba bersih dibanding dengan total penjualannya juga dapat menunjukan seberapa besar biaya operasional dapat ditekan sehingga dapat memprediksi seberapa besar pendapatan yang akan dihasilkan di masa depan. Pada akhirnya laba bersih ini juga akan akan berpengaruh pada dividen untuk investor. Rasio profitabilitas diukur menggunakan Net Profit Margin (NPM), rasio ini menunjukan perbandingan laba bersih sebelum pajak dengan total pendapatan. Net Profit Margin (NPM) menunjukan besarnya laba bersih perusahaan semakin besar rasionya berarti semakin besar laba bersih yang diperoleh dari pendapatannya. Semakin besar laba bersih berarti semakin besar kemungkinan dividen yang dapat diperoleh sehingga berpengaruh pada peningkatan harga saham. Oleh karena itu ditarik hipotesis sebagai berikut.

H5: Net Profit Margin (NPM) berpengaruh positif terhadap harga saham.

\section{Metode Penelitian}

Jenis data yang digunakan dalam penelitian ini adalah data sekunder yang diperoleh dari website Bursa Efek Indonesia http://www.idx.co.id selama periode 2010-2017. Sampel penelitian ini adalah perusahaan Perbankan BUMN yang terdaftar di Bursa Efek Indonesia selama periode pengamatan 2010-2017, dengan kriteria sampel secara purposive sampling, yakni :

- Perusahaan perbankan terdaftar di Bursa Efek Indonesia selama periode pengamatan (20102017).

- Perusahaan perbankan merupakan milik BUMN minimal sebesar 50\% selama periode pengamatan (2010-2017).

- Perusahaan telah memperoleh laba dan membagikan dividen minimal sebanyak 5 kali selama periode pengamatan. 
- Memiliki ketersedian data dalam laporan keuangan yang digunakan dalam variabel penelitian meliputi Non Performance Loans (NPL), Return On Assets (ROA), Capital Adequacy Ratio (CAR), Price Earnings Ratio ( PER), dan Net Profit Margin (NPM).

Berdasarkan kriteria sampel tersebut diperoleh sebanyak 4 perusahaan, meliputi 4 bank yakni: PT. Bank Rakyat Indonesia (Persero) Tbk., PT. Bank Mandiri (Persero) Tbk., PT. Bank Negara Indonesia (Persero) Tbk., dan PT. Bank Tabungan Negara (Persero) Tbk.

Variabel Penelitian Dan Definisi Operasional Variabel yang digunakan pada penelitian ini meliputi:

1. Variabel Dependen (Y)

Variabel dependen dalam penelitian ini adalah harga saham. Harga saham yang digunakan adalah harga saham penutupan per 31 Maret yang terpublikasi di Bursa Efek Indonesia.

2. Variabel Independen (X)

Variabel bebas yang digunakan dalam penelitian ini adalah:

a. Non Performing Loan(NPL)

NPL ini merupakan kredit bermasalah yang merupakan salah satu kunci untuk menilai kualitas kinerja bank. Ini artinya NPL merupakan indikasi adanya masalah dalam bank tersebut yang mana jika tidak segera mendapatkan solusi maka akan berdampak bahaya pada bank. Rumus untuk menghitung Non Performing Loan perusahaan adalah sebagai berikut:

Total Kredit Bermasalah

Non Performing Loan = -------------------------------

Total Kredit

b. Return On Assets(ROA)

Return On Assets adalah tingkat pengembalian aset adalah rasio profitabilitas yang menunjukan persentase laba bersih yang diperoleh perusahaan sehubungan dengan keseluruhan sumber daya. Dengan kata lain, ROA mengukur seberapa efisien suatu perusahaan dalam mengelola asetnya untuk menghasilkan laba selama suatu periode. Rumus untuk menghitung Return On Assets perusahaan adalah sebagai berikut:

Laba Bersih Setelah Pajak

Return On Assets $=$-------------
Total Aset

c. Capital Adequacy Ratio(CAR)

Modal merupakan faktor utama bagi suatu bank untuk dapat mengembangkan pertumbuhan usahanya. Pemenuhan kebutuhan Rasio Modal Minimal Bank atau dikenal CAR ditentukan oleh BIS (Bank for International Setlement) sebesar 8\%. Rumus untuk menghitung Capital Adequacy Ratio perusahaan adalah sebagai berikut:

Capital Adequacy Ratio $=$
----odal
Aktiva Tertimbang Menurut Risiko 


\section{d. Price Earning Ratio (PER)}

PER dikenal sebagai salah satu indikator terpenting di pasar modal. Definisi dari rasio ini adalah suatu rasio yang menggambarkan bagaimana keuntungan perusahaan terhadap harga sahamnya. Dengan menghitung PER kita dapat mengetahui berapa lama waktu yang diperlukan untuk dapat memperoleh kembali modal pokoknya. Rumus untuk menghitung Price Earning Ratio perusahaan adalah sebagai berikut:

$$
\text { Price Earning Ratio = } \frac{\text { Harga Saham }}{\text { Laba per Saham }}
$$

e. Net Profit Margin (NPM)

Bagi Investor, Marjin Laba Bersih atau Net Profit Margin adalah untuk mengukur seberapa efisien manajemen mengelola perusahaannya dan juga memperkirakan profitabilitas masa depan berdasarkan peramalan penjualan yang dibuat oleh manajemennya. Rumus untuk menghitung Net Profit Margin perusahaan adalah sebagai berikut:

\begin{tabular}{|c|c|}
\hline & Laba Bersih Setelah Pajak \\
\hline & Total Pendapatan \\
\hline
\end{tabular}

Berdasarkan pada latar belakang dan hipotesis yang telah dikemukakan, dapat dirumuskan model dari penelitian ini seperti ditunjukkan pada Gambar 1.

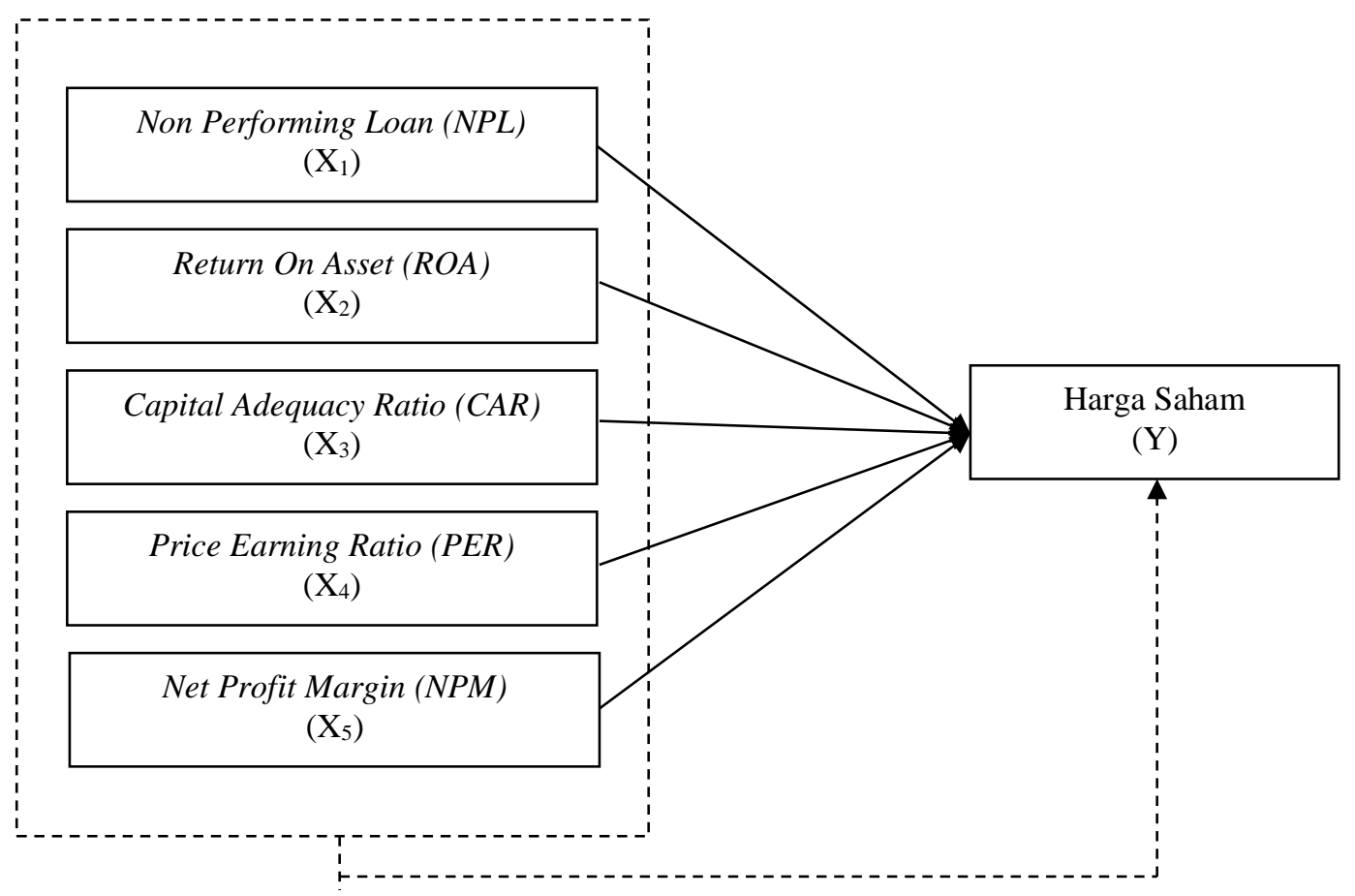

\section{Gambar 1. Model Kerangka Konseptual Penelitian}


Teknik analisis data dalam penelitian ini meliputi Uji asumsi klasik yang terdiri dari Uji normalitas, uji multikolinieritas, Uji autokorelasi, dan uji heterokedastisitas. Sedangkan pengujian hipotesis menggunakan Regresi Linier Berganda, yang meliputi uji $\mathrm{F}$ dan Uji $\mathrm{T}$. Model Persamaan Regresi Linier bergandanya adalah:

$\mathrm{Y}=\alpha+\mathrm{b} 1 \mathrm{X} 1+\mathrm{b} 2 \mathrm{X} 2+\mathrm{b} 3 \mathrm{X} 3+\mathrm{b} 4 \mathrm{X} 4+\mathrm{b} 5 \mathrm{X} 5+\mathrm{e}$

\section{Hasil Penelitian dan Pembahasan}

Teknik analisis data deskriptif digunakan untuk mendeskriptifkan variabel-variabel dalam penelitian yang akan memberikan gambaran umum dari setiap variabel penelitian. Alat analisis yang digunakan adalah nilai rata-rata (mean), distribusi frekuensi, nilai minimum dan serta deviasi standar (Ghozali, 2011).

Tabel 1: Analisis Deskriptif Non Performing Loan, Return On Assets, Capital Adequacy Ratio, Price Earning Ratio, dan Net Profit Margin

\begin{tabular}{|c|c|c|c|c|c|c|c|}
\hline Kode & Nama Perusahaan & Tahun & NPL (\%) & ROA (\%) & CAR (\%) & PER (\%) & $\operatorname{NPM}(\%)$ \\
\hline \multirow[t]{8}{*}{ BBRI } & \multirow{8}{*}{$\begin{array}{l}\text { PT Bank Rakyat } \\
\text { Indonesia (Persero) } \\
\text { Tbk }\end{array}$} & 2010 & $2,78 \%$ & $4,64 \%$ & $13,76 \%$ & $11,60 \%$ & $34,88 \%$ \\
\hline & & 2011 & $2,30 \%$ & $3,21 \%$ & $14,96 \%$ & $10,94 \%$ & $43,83 \%$ \\
\hline & & 2012 & $1,78 \%$ & $3,39 \%$ & $16,95 \%$ & $8,66 \%$ & $51,22 \%$ \\
\hline & & 2013 & $1,55 \%$ & $3,41 \%$ & $16,99 \%$ & $9,04 \%$ & $48,42 \%$ \\
\hline & & 2014 & $1,69 \%$ & $3,02 \%$ & $18,31 \%$ & $7,40 \%$ & $47,07 \%$ \\
\hline & & 2015 & $2,02 \%$ & $2,89 \%$ & $20,59 \%$ & $9,02 \%$ & $43,60 \%$ \\
\hline & & 2016 & $2,03 \%$ & $2,61 \%$ & $22,91 \%$ & $8,26 \%$ & $40,01 \%$ \\
\hline & & 2017 & $2,10 \%$ & $2,57 \%$ & $22,96 \%$ & $6,59 \%$ & $39,72 \%$ \\
\hline \multirow[t]{8}{*}{ BMRI } & \multirow{8}{*}{$\begin{array}{l}\text { PT Bank Mandiri } \\
\text { (Persero) Tbk }\end{array}$} & 2010 & $2,40 \%$ & $2,05 \%$ & $13,40 \%$ & $6,46 \%$ & $47,23 \%$ \\
\hline & & 2011 & $2,20 \%$ & $2,22 \%$ & $15,30 \%$ & $7,73 \%$ & $56,24 \%$ \\
\hline & & 2012 & $1,70 \%$ & $2,44 \%$ & $15,50 \%$ & $6,64 \%$ & $54,55 \%$ \\
\hline & & 2013 & $1,60 \%$ & $2,48 \%$ & $14,90 \%$ & $8,26 \%$ & $53,84 \%$ \\
\hline & & 2014 & $1,70 \%$ & $2,32 \%$ & $16,60 \%$ & $6,83 \%$ & $50,78 \%$ \\
\hline & & 2015 & $2,30 \%$ & $2,23 \%$ & $18,60 \%$ & $8,46 \%$ & $44,83 \%$ \\
\hline & & 2016 & $3,96 \%$ & $1,79 \%$ & $21,40 \%$ & $10,11 \%$ & $35,92 \%$ \\
\hline & & 2017 & $3,45 \%$ & $2,42 \%$ & $21,60 \%$ & $5,76 \%$ & $51,92 \%$ \\
\hline \multirow[t]{8}{*}{ BBNI } & \multirow{8}{*}{$\begin{array}{l}\text { PT Bank Negara } \\
\text { Indonesia (Persero) } \\
\text { Tbk }\end{array}$} & 2010 & $4,30 \%$ & $1,65 \%$ & $18,60 \%$ & $6,69 \%$ & $34,96 \%$ \\
\hline & & 2011 & $3,60 \%$ & $1,95 \%$ & $17,60 \%$ & $7,80 \%$ & $44,15 \%$ \\
\hline & & 2012 & $2,80 \%$ & $2,11 \%$ & $16,70 \%$ & $7,49 \%$ & $45,58 \%$ \\
\hline & & 2013 & $2,20 \%$ & $2,34 \%$ & $15,10 \%$ & $9,80 \%$ & $47,51 \%$ \\
\hline & & 2014 & $2,00 \%$ & $2,59 \%$ & $16,20 \%$ & $8,00 \%$ & $47,37 \%$ \\
\hline & & 2015 & $2,70 \%$ & $1,78 \%$ & $19,50 \%$ & $9,37 \%$ & $35,47 \%$ \\
\hline & & 2016 & $3,00 \%$ & $1,88 \%$ & $19,40 \%$ & $9,42 \%$ & $37,80 \%$ \\
\hline & & 2017 & $2,30 \%$ & $1,92 \%$ & $18,50 \%$ & $8,41 \%$ & $42,63 \%$ \\
\hline \multirow[t]{8}{*}{ BBTN } & \multirow{8}{*}{$\begin{array}{l}\text { PT Bank Tabungan } \\
\text { Negara (Persero) } \\
\text { Tbk }\end{array}$} & 2010 & $3,26 \%$ & $1,34 \%$ & $16,74 \%$ & $6,52 \%$ & $27,30 \%$ \\
\hline & & 2011 & $2,75 \%$ & $1,26 \%$ & $15,03 \%$ & $10,70 \%$ & $29,56 \%$ \\
\hline & & 2012 & $4,09 \%$ & $1,22 \%$ & $17,69 \%$ & $8,71 \%$ & $28,86 \%$ \\
\hline & & 2013 & $4,05 \%$ & $1,19 \%$ & $15,62 \%$ & $11,52 \%$ & $27,63 \%$ \\
\hline & & 2014 & $4,01 \%$ & $0,79 \%$ & $14,64 \%$ & $8,61 \%$ & $20,97 \%$ \\
\hline & & 2015 & $3,42 \%$ & $1,08 \%$ & $16,97 \%$ & $10,03 \%$ & $27,18 \%$ \\
\hline & & 2016 & $2,84 \%$ & $1,22 \%$ & $20,34 \%$ & $10,88 \%$ & $32,08 \%$ \\
\hline & & 2017 & $2,66 \%$ & $1,16 \%$ & $18,87 \%$ & $7,53 \%$ & $32,41 \%$ \\
\hline \multicolumn{3}{|c|}{ Maksimum } & $4,30 \%$ & $4,64 \%$ & $22,96 \%$ & $11,60 \%$ & $56,24 \%$ \\
\hline \multicolumn{3}{|c|}{ Minimum } & $1,55 \%$ & $0,79 \%$ & $13,40 \%$ & $5,76 \%$ & $20,97 \%$ \\
\hline \multicolumn{3}{|l|}{ Mean } & $2,67 \%$ & $2,16 \%$ & $17,57 \%$ & $8,54 \%$ & $40,80 \%$ \\
\hline
\end{tabular}


Hasil analisis deskriptif yang ditunjukkan pada Tabel 1, yang menghasilkan serangkaian informasi sebagai berikut:

1. Variabel Non Performing Loan memperoleh nilai tertinggi sebesar 4,30\% yang diperoleh oleh PT Bank Negara Indonesia (Persero) Tbk pada tahun 2010 sedangkan nilai terendahnya adalah 1,55\% yang diperoleh oleh PT Bank Rakyat Indonesia (Persero) Tbk pada tahun 2013 dan rata-rata dari rasio keuangan ini adalah 2,67\%.

2. Variabel Return On Assets memperoleh nilai tertinggi sebesar 4,64\% yang diperoleh oleh PT Bank Rakyat Indonesia (Persero) Tbk pada tahun 2010 sedangkan nilai terendahnya adalah 0,79\% yang diperoleh oleh PT Bank Tabungan Negara (Persero) Tbk pada tahun 2014 dan rata-rata dari rasio keuangan ini adalah 2,16\%.

3. Variabel Capital Adequacy Ratio memperoleh nilai tertinggi sebesar 22,96\% yang diperoleh oleh PT Bank Rakyat Indonesia (Persero) Tbk pada tahun 2017 sedangkan nilai terendahnya adalah 13,40\% yang diperoleh oleh PT Bank Mandiri (Persero) Tbk pada tahun 2010 dan rata-rata dari rasio keuangan ini adalah $17,57 \%$.

4. Variabel Price Earning Ratio memperoleh nilai tertinggi sebesar 11,60\% yang diperoleh oleh PT Bank Rakyat Indonesia (Persero) Tbk pada tahun 2013 sedangkan nilai terendahnya adalah 5,76\% yang diperoleh oleh PT Bank Mandiri (Persero) Tbk pada tahun 2017 dan ratarata dari rasio keuangan ini adalah $8,54 \%$.

5. Variabel Net Profit Margin memperoleh nilai tertinggi sebesar 56,24\% yang diperoleh oleh PT Bank Mandiri (Persero) Tbk pada tahun 2011 sedangkan nilai terendahnya adalah 20,97\% yang diperoleh oleh PT Bank Tabungan Negara (Persero) Tbk pada tahun 2014 dan rata-rata dari rasio keuangan ini adalah $40,80 \%$.

Langkah selanjutnya adalah uji asumsi klasik yang terdiri dari uji normalitas, heteroskedastisitas, autokorelasi dan multikolinearitas. Dalam penelitian ini cara untuk mendeteksi normalitas adalah dengan melihat nilai signifikansi dari hasil test Kolmogorv Smirnov menggunakan SPSS 23.

Tabel 2. Uji Normalitas Kolmogorov Smirnov

\begin{tabular}{llr}
\hline \multicolumn{2}{c}{ One-Sample Kolmogorov-Smirnov Test } \\
\hline $\mathrm{N}$ & & $\begin{array}{r}\text { Unstandardized } \\
\text { Residual }\end{array}$ \\
\hline Normal Parameters & & 32 \\
& Mean &, 0000000 \\
\hline Most Extreme Differences & Std. Deviation &, 16697975 \\
\cline { 2 - 3 } & Absolute &, 110 \\
\cline { 2 - 3 } & Positive &, 110 \\
\cline { 2 - 3 } & Negative &,- 075 \\
\hline Test Statistic & &, 110 \\
\hline Asymp. Sig. (2-tailed) &, $200^{\mathrm{c}, \mathrm{d}}$ \\
\hline a. Test distribution is Normal. & \\
\hline b. Calculated from data. & \\
\hline c. Lilliefors Significance Correction. & \\
\hline d. This is a lower bound of the true significance. & \\
\hline
\end{tabular}

Pada hasil uji di Tabel 2 didapati nilai signifikansi uji ini > 0,05 yang berarti sampel dari uji Kolmogorov Smirnov berdistribusi normal.

Uji heterokedastisitas dapat dilihat dengan menggunakan Scatterplot antara nilai prediksi variabel terikat (ZPRED) dengan residual (SRESID). Hasil uji heterokedastisitas menunjukkan tidak ada pola yang membentuk sehingga dapat dikatakan tidak terjadi heterokedastisitas (seperti ditunjukkan pada Gambar 2. 


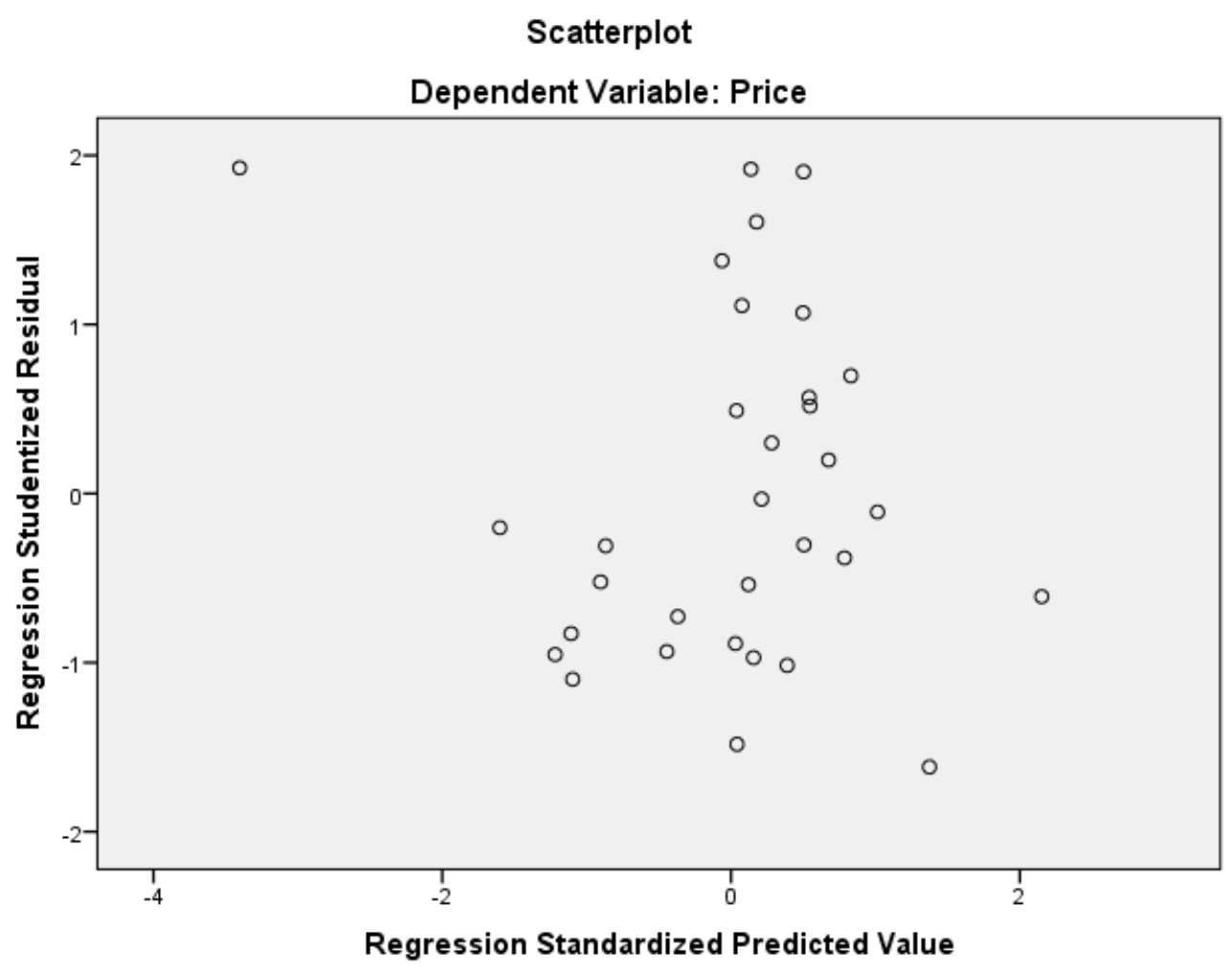

Gambar 2. Scatterplot Residual Data Penelitian

Hasil pengujian autokorelasi dengan menggunakan run test menunjukkan tidak terjadi gejala autokorelasi, terlihat dari nilai signifikansi dari test ini > 0,05 i

Tabel 3. Uji Autokorelasi Runs Test

\begin{tabular}{lr}
\hline \multicolumn{2}{c}{ Runs Test } \\
\hline & Unstandardized Residual \\
\hline Test Value $^{\mathrm{a}}$ &,- 03889 \\
\hline Cases $<$ Test Value & 16 \\
\hline Cases $>=$ Test Value & 16 \\
\hline Total Cases & 32 \\
\hline Number of Runs & 13 \\
\hline Z & $-1,258$ \\
\hline Asymp. Sig. (2-tailed) &, 208 \\
\hline a. Median & \\
\hline
\end{tabular}

Uji mutikolinearitas dilihat dari nilai Tolerance dan Variance Inflation Factor (VIF) (Ghozali, 2011). Untuk mendeteksi adanya problem multikolinieritas, maka dapat dilakukan dengan melihat nilai Tolerance dan VIF serta besaran korelasi anta variabel independen. Regresi yang baik memiliki VIF di sekitar angka 1 (satu) dan mempunyai angka Tolerance mendekati 1 (Ghozali, 2011). 
Tabel 4. Tabel Multikolinieritas Tolerance dan Variance Inflation Factor

\begin{tabular}{ccccccc}
\hline \multirow{2}{*}{ Model } & \multicolumn{5}{c}{ Correlations } & \multicolumn{3}{c}{ Collinearity Statistics } \\
\cline { 2 - 6 } & B & Zero-order & Partial & Part & Tolerance & VIF \\
\hline (Constant) & 2,085 & & & & & \\
\hline NPL &, 042 &,- 189 &, 136 &, 082 &, 446 & 2,243 \\
\hline ROA &,- 169 &,- 072 &,- 510 &,- 354 &, 494 & 2,023 \\
\hline CAR &, 039 &, 356 &, 498 &, 343 &, 933 & 1,072 \\
\hline PER &,- 014 &,- 522 &,- 105 &,- 063 &, 646 & 1,548 \\
\hline NPM &, 027 &, 517 &, 652 &, 514 &, 328 & 3,053 \\
\hline
\end{tabular}

Berdasarkan hasil output tabel 5 diketahui dari nilai Tolerance dan VIF kelima variabel tidak terdapat multikolinieritas dimana nilai Tolerancenya dibawah 1 masing-masing 0,446; 0,$494 ; 0,933 ; 0,646 ; 0,328$ dan nilai VIF dari masing-masing variabel juga sudah berada diatas 1 yaitu 2,243; 2,023; 1,072; 1,548; 3,053. Dari hasil uji mutikolinieritas diatas dapat disimpulkan bahwa data tidak terjadi multikolinieritas.

Berdasarkan pengujian persamaan regresi pengaruh Non Performing Loan, Return On Assets, Capital Adequacy Ratio, Price Earning Ratio, dan Net Profit Margin terhadap harga saham maka pengujian hipotesis penelitian dapat dianalisis berdasarkan hasil output SPSS dari regresi linier berganda sebagai berikut:

$\mathrm{Y}=2,195+0,051 \mathrm{X} 1+(0,152) \mathrm{X} 2+0,039 \mathrm{X} 3+(0,022) \mathrm{X} 4+0,024 \mathrm{X} 5+\mathrm{e}$

Berdasarkan hasil analisis koefisien determinasi dapat diketahui nilai Adjusted $\mathrm{R}$ Square $\left(\mathrm{R}^{2}\right)$ sebagai koefisien determinasi sebesar 0,575. Koefisien determinasi tersebut menggambarkan bahwa variabel Non Performing Loan, Return On Assets, Capital Adequacy Ratio, Price Earning Ratio, dan Net Profit Margin mampu menjelaskan variabel harga saham sebesar 57,5\% sedangkan sisanya sebesar $42,5 \%$ dijelaskan oleh variabel lain yang tidak dimasukan dalam model penelitian ini. Hal ini menunjukkan masih banyak faktor - faktor lain yang berpengaruh terhadap harga saham seperti kestabilan ekonomi, tahun politik dan sebagainya.

Tabel 5. Model Summary Koefisien Determinasi

\begin{tabular}{ccccc}
\hline \multicolumn{3}{c}{ Model Summary $^{\mathbf{b}}$} \\
\hline Model & $\mathrm{R}$ & R Square & Adjusted R Square & Std. Error of the Estimate \\
\hline 1 &, $802^{\mathrm{a}}$ &, 644 &, 575 &, 1823 \\
\hline a. Predictors: (Constant), NPM, CAR, PER, ROA, NPL & \\
\hline \multicolumn{2}{l}{ b. Dependent Variable: Price } \\
\hline
\end{tabular}

Berdasarkan hasil tabel 7 , dapat dilihat nilai signifikansi model regresi secara simultan sebesar 0,000. Nilai ini lebih kecil dari taraf signifikansi yaitu 0,000 $<0,05$, dengan demikian secara simultan Non Performing Loan, Return On Assets, Capital Adequacy Ratio, Price Earning Ratio, dan Net Profit Margin berpengaruh terhadap harga saham.

\section{Tabel 6. Tabel ANOVA}

\begin{tabular}{ccccccc}
\hline \multicolumn{7}{c}{ ANOVA $^{\mathbf{a}}$} \\
\hline Model & Sum of Squares & df & Mean Square & F & Sig. \\
\hline 1 & Regression & 1,563 & 5 &, 313 & 9,401 &, $000^{\mathrm{b}}$ \\
\cline { 2 - 7 } & Residual &, 864 & 26 &, 033 & & \\
\hline Total & 2,427 & 31 & & \\
\hline
\end{tabular}

a. Dependent Variable: Price

b. Predictors: (Constant), NPM, CAR, PER, ROA, NPL 
Berdasarkan hasil tabel 6, dapat dilihat nilai signifikansi model regresi secara simultan sebesar 0,000. Nilai ini lebih kecil dari taraf signifikansi yaitu $0,000<0,05$, dengan demikian secara simultan Non Performing Loan, Return On Assets, Capital Adequacy Ratio, Price Earning Ratio, dan Net Profit Margin berpengaruh terhadap harga saham. Untuk pengujiannya secaca parsial:

\section{Tabel 7. Coefficients Uji t}

\begin{tabular}{|c|c|c|c|c|c|}
\hline \multicolumn{6}{|c|}{ Coefficients $^{\mathrm{a}}$} \\
\hline \multirow[t]{2}{*}{ Model } & Unstandardized & Coefficients & Standardized Coefficients & $\mathrm{t}$ & Sig. \\
\hline & $\mathrm{B}$ & Std. Error & Beta & & \\
\hline 1 (Constant) & 2,085 &, 557 & & 3,742 & ,001 \\
\hline NPL &, 042 &, 059 &, 123 & ,702 & , 489 \\
\hline ROA &,- 169 & ,056 &,- 503 & $-3,024$ & ,006 \\
\hline CAR & 039 &, 013 &, 355 & 2,929 &, 007 \\
\hline PER &,- 014 &, 026 &,- 078 &,- 537 & ,596 \\
\hline NPM &, 027 &, 006 & ,897 & 4,388 &, 000 \\
\hline
\end{tabular}

a. Dependent Variable: Price

Berdasarkan tabel 7, hasl pengujian secara parsial adalah sebagai berikut:

1. Pengaruh Non Performing Loan terhadap harga saham

Berdasarkan uji $\mathrm{T}$ pada model regresi, dapat diperoleh nilai signifikansi variabel Non Performing Loan sebesar 0,489 > 0,05 (taraf signifikansi) dan dari hasil perbandingan $\mathrm{t}$ hitung dan $t$ tabel dapat dilihat nilai t hitung sebesar 0,702 sedangkan $t$ tabel 2,037. Dari hasil tersebut bisa dilihat bahwa thitung $<\mathrm{t}$ tabel yaitu $0,702<2,037$ maka dapat disimpulkan $\mathrm{H} 1$ ditolak yang artinya secara parsial Non Performing Loan tidak berpengaruh terhadap harga saham. Penelitian kali ini tidak mendukung hasil penelitian yang dilakukan oleh Marwansyah (2016) yang menyatakan Non Performing Loan berpengaruh terhadap harga saham. Non Performing Loan merupakan salah satu indikator kesehatan kualitas aset bank. Non Performing Loan tidak berpengaruh terhadap harga saham perusahaan perbankan BUMN di Bursa Efek sebagian besar dipengaruhi oleh kepemilikan perusahaan tersebut yang dikuasai oleh negara. Akibat dari kepemilikan negara dalam struktur permodalan perusahaan ini adalah adanya sokongan modal yang sangat besar yang memberikan kestabilan ekonomi lebih kuat sehingga tidak terpengaruh oleh risiko yang ditimbulkan oleh kredit macet

2. Pengaruh Return On Assets terhadap harga saham

Hasil penelitian dari uji t menunjukkan bahwa p-val sebesar 0,006 $<0,05$ (taraf signifikansi). Dari hasil tersebut bisa dilihat bahwa thitung $>\mathrm{t}$ tabel yaitu 3,024 $>2,037$ sehingga secara statistik dapat disimpulkan $\mathrm{H} 2$ ditolak. Hasil penelitian ini sejalan dengan penelitian yang dilakukan oleh Marwansyah (2016). Return On Assets merupakan indikator untuk mengetahui seberapa menguntungkan suatu perusahaan relatif terhadap total aset. Perhitungan rasio Return On Assets dapat memberikan wawasan bagi manajer, analis, investor tentang seberapa efisien manajemen perusahaan menggunakan asetnya untuk menghasilkan profit. Namun dalam penelitian ini Return On Assets menunjukan pengaruh negatif hal ini disebabkan oleh pertumbuhan aset lebih besar dari pada laba yang diperoleh. Aset di perusahaan ini pertumbuhannya lebih besar dikarenakan banyaknya investasi dan simpanan oleh nasabah baik dalam bentuk tabungan dan deposito hal ini juga menimbulkan banyaknya beban bunga yang besar pada pendapatan perusahaan sehingga mengurangi laba bersih perusahaan. Namun investor melihat kejadian tersebut sebagai sesuatu yang baik karena memberikan bank tambahan modal untuk kredit sehingga memperoleh kesempatan untuk mendapat laba lebih besar. 
3. Pengaruh Capital Adequacy Ratio terhadap harga saham

Hasil pengujian Capital Adequacy Ratio sebesar 0,007 < 0,05 (taraf signifikansi). maka dapat disimpulkan $\mathrm{H} 3$ diterima yang artinya secara parsial Capital Adequacy Ratio berpengaruh positif terhadap harga saham. Hasil penelitian ini tidak mendukung hasil penelitian Apriliyanti (2015) dan Marwansyah (2016) yang menyatakan Capital Adequacy Ratio tidak berpengaruh terhadap harga saham. Rasio kecukupan modal merupakan rasio yang merepresentasikan kemampuan bank dalam menyediakan dana yang digunakan sebagai cadangan untuk mengatasi kemungkinan terjadinya risiko kerugian. Definisi tersebut memperlihatkan bahwa seluruh aktiva yang dimiliki lembaga perbankan baik berupa kredit, penyertaan, surat berharga, maupun tagihan pada bank lain mengandung risiko yang harus dibiayai dari modal sendiri dan juga dana-dana yang diperoleh dari sumber lain seperti dana dari masyarakat berupa tabungan, giro, deposito, dan lainnya. Jadi, rasio kecukupan modal ini merupakan indikator kemampuan bank menutupi penurunan aktiva yang terjadi sebagai akibat dari timbulnya kerugian-kerugian yang disebabkan oleh aktiva yang berisiko.

4. Pengaruh Price Earning Ratio terhadap harga saham

Hipotesis H4 menyatakan bahwa Price Earning Ratio berpengaruh negatif terhadap harga saham ditolak. Hal tersebut terlihat dari hasil uji T menunjukkan bahwa p-val PER sebesar $0,596>0,05$ (taraf signifikansi). Hasil penelitian ini sejalan dengan penelitian yang dilakukan oleh Ratri (2015) \& Wardani (2018). Tetapi tidak mengkonfirmasi hasil penelitian Apriliyanti (2015) \& Halim (2018). PER adalah sebuah variable yang menggambarkan psikologis dari pasar, yaitu berupa ekspektasi dan persepsi pasar terhadap suatu saham.

5. Pengaruh Net Profit Margin terhadap harga saham

Hasil uji $\mathrm{T}$ menunjukkan bahwa $\mathrm{p}$-val sebesar sebesar $0,000<0,05$ (taraf signifikansi) sehingga hipotesis H5 yang menyatakan bahwa Net Profit Margin berpengaruh positif terhadap harga saham dapat diterima. Net Profit margin ini adalah kemampuan perusahaan dalam membuat laba secara efisien. Perusahaan yang memiliki profit margin besar berarti perusahaan tersebut efisien dan produknya lebih menguntungkan dibandingkan dengan perusahaan yang memiliki profit margin lebih kecil.

\section{Kesimpulan}

Hasil penelitian menunjukkan bahwa kinerja keuangan perbankan yang di proksikan dengan rasio-rasio keuangan yang meliputi rasio Non Performing Loan, Return On Assets, Capital Adequacy Ratio, Price Earning Ratio, dan Net Profit Margin secara simultan berpengaruh terhadap harga saham. Sedangkan hasil pengujian secara parsial menunjukkan bahwa variabel yang berpengaruh terhadap harga saham perusahaan perbankan BUMN yang terdaftar di Bursa Efek Indonesia adalah return on assets (ROA), Capital Adequacy Ratio, (CAR) dan Net profit Marghin (NPM), sedangkan variabel Non performing Loan (NPL) dan Price Earnings Ratio (PER) tidak berpengaruh terhadap harga saham.

Bagi investor agar dapat mempertimbangkan berbagai faktor jika ingin membeli saham di Bursa Efek Indonesia seperti faktor fundamental dan teknikal, faktor di luar keuangan, dan faktor psikologi investor. Bagi penelitian selanjutnya disarankan agar menambahkan variabel - variabel di luar faktor keuangan seperti kebijakan pemerintah, kondisi geopolitik dan perkembangan teknologi, dll agar hasil penelitian dapat lebih menggambarkan perubahan dari harga sahamnya. 


\section{DAFTAR PUSTAKA}

Apriliyanti, D. A. (2015). Analisis Pengaruh Kinerja Keuangan Terhadap Harga Saham Perusahaan Perbankan di Bursa Efek Indonesia. Surakarta: Universitas Muhammadiyah Surakarta.

Armania. (2017). Pengaruh Kinerja Keuangan Terhadap Harga Saham Pada Perusahaan Sektor Properti dan Real Estate yang Terdaftar di Bursa Efek Indonesia Tahun 2012-2015. Bandar Lampung: Universitas Lampung.

Cahriri, \& Ghozali, A. (2007). Teori Akuntansi. Yogyakarta: Penerbit Andi.

Dendawijaya, L. (2004). Manajemen Perbankan. Jakarta: Penerbit Ghalia Indonesia.

Fahmi, I. (2012). Manajemen Investasi (Teori dan Soal Jawab). Jakarta: Salemba Empat.

Ghozali, I. (2011). Aplikasi Analisis Multivariate Dengan Program SPSS. Semarang: Badan Penerbit Universitas Diponegoro.

Halim, D. (2018). Faktor-Faktor yang Memengaruhi Harga Saham Pada Perusahaan Property dan Real Estate yang Terdaftar di Bursa Efek Indonesia. Banjarmasin: Sekolah Tinggi Ilmu Ekonomi Indonesia.

Marwansyah, S. (2016). Analisis Kinerja Keuangan Terhadap Harga Saham pada Bank BUMN. Jakarta: Akademi Manajemen Keuangan BSI.

Ratri, T. D. (2015). Pengaruh Kinerja Keuangan Terhadap Harga Saham Perusahaan Tekstil dan Produk Tekstil (TPT) yang Terdaftar di Bursa Efek Indonesia Tahun 2009-2014. Yogyakarta: Univesitas Negeri Yogyakarta.

Santoso, S. (2010). Statistik Multivariat Konsep dan Aplikasi Dengan SPSS. Jakarta: PT Elex Media Komputindo.

Sartono, A. (2005). Manajemen Keuangan. Edisi Keempat. Yogyakarta: Badan Penerbit Fakultas Ekonomi UGM.

Siamat, D. (1993). Manajemen Bank Umum. Jakarta: Intermedia.

Wardani, T. (2018). Faktor-Faktor yang Memengaruhi Harga Saham Pada Perusahaan Property dan Real Estate yang Terdaftar di Bursa Efek Indonesia. Banjarmasin: Sekolah Tinggi Ilmu Ekonomi Indonesia. 